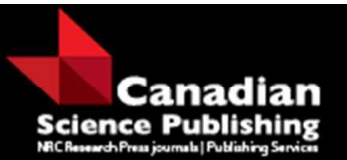

Canadian Journal of Forest Research Revue canadienne de recherche forestière

\title{
Red hot maples: Acer rubrum first-year phenology and growth responses to soil warming
}

\begin{tabular}{|r|l|}
\hline Journal: & Canadian Journal of Forest Research \\
\hline Manuscript ID & cjfr-2016-0288.R1 \\
\hline Danuscript Type: & Article \\
\hline Complete List of Authors: & $\begin{array}{l}\text { Wheeler, Julia; University of Massachusetts Amherst, Environmental } \\
\text { Conservation } \\
\text { Gonzalez, Natalie; Fullerton College, Biology } \\
\text { Stinson, Kristina; University of Massachusetts Amherst, Environmental } \\
\text { Conservation }\end{array}$ \\
\hline Keyword: & $\begin{array}{l}<\text { i>Acer rubrum</i>, soil temperature, leaf phenology, leaf production, } \\
\text { biomass allocation }\end{array}$ \\
\hline &
\end{tabular}

SCHOLARONE ${ }^{\text {'t }}$

Manuscripts 
1 Red hot maples: Acer rubrum first-year phenology and growth responses to soil warming

2

3 Wheeler, J.A. ${ }^{1}$, Gonzalez, N.M. ${ }^{2}$ and Stinson, K.A. ${ }^{1}$

4

51 Department of Environmental Conservation, University of Massachusetts, Amherst, MA, USA

62 Fullerton College, Fullerton, CA, USA

7

8 Corresponding author: J.A.Wheeler

$9 \quad$ Email: juliawheeler@umass.edu 
12 Microhabitat environmental conditions are an important filter for seedling establishment,

13 controlling the availability of optimal recruitment sites. Understanding how tree seedlings

14 respond to warming soil temperature is critical for predicting population recruitment in the future

15 hardwood forests of northeastern North America, particularly as environmental conditions and

16 thus optimal microhabitat availabilities change. We examined the effect of $5^{\circ} \mathrm{C}$ soil warming

17 during the first growing season on germination, survival, phenology, growth, and stem and root

18 biomass allocation in Acer rubrum (red maple) seedlings. While there was no effect of soil

19 warming on germination or survival, seedlings growing in warmer soils demonstrated

20 significantly accelerated leaf expansion, delayed autumn leaf senescence, and an extended leaf

21 production period. Further, seedlings growing in warmer soils showed larger leaf area, stem and

22 root structures at the end of the first growing season, with no evidence of biomass allocation

23 tradeoffs. Results suggest A. rubrum seedlings can capitalize on soil warming by adjusting leaf

24 phenology and leaf production, resulting in a longer period of carbon uptake and leading to

25 higher overall biomass. The absence of growth allocation tradeoffs suggests $A$. rubrum will

26 respond positively to increasing soil temperatures in northeastern forests, at least in the early life

27 stages.

28 KEYWORDS

29 Acer rubrum; soil temperature; leaf phenology; leaf production; biomass allocation 


\section{INTRODUCTION}

The regeneration and future distribution of forest tree species depend largely on conditions within the microhabitat at early stages of recruitment, because local environmental conditions act as a filter for germination, emergence and survival of individual seedlings ( Harper 1977). Soil temperature in the seedling microhabitat is known to influence survival and recruitment of woody plants across a range of taxa and community types, from Mediterranean communities to deciduous forest to alpine tundra (Caldeira et al. 2014, Castro et al. 2011, Utsugi et al. 2006). Fine-scaled soil temperature and related effects on seedling performance may be driven in part by microtopography (Schmidt et al. 1998) but changes in broader climate conditions are also known to increase local soil temperatures (Qian et al. 2011). Therefore, ongoing anthropogenic changes in climate that affect local soil temperature can have important consequences for tree recruitment, via effects on seedling emergence (Thompson and Naeem 1996) and growth (Rogiers et al. 2014).

Climate warming up to $5^{\circ} \mathrm{C}$ is predicted to affect temperate deciduous forests in northeastern North America in the next century (IPCC 2013), and a number of ecological studies use experimental soil warming to understand how concomitant forest floor surface temperature changes can alter ecosystem processes (Frey et al. 2013). Soil warming improves microhabitat conditions for seedlings of some hardwood species (Rogiers et al. 2014) but has a detrimental effect on others (Danyagri et.al. 2014). Further, soil warming can increase growth in belowground structures while having less impact on aboveground structures like leaves (Štraus et al. 2015), and lead to changes in patterns of biomass allocation. Compared to atmospheric 
53 warming (Norby et al. 2003, Wertin et al. 2011, Searle et al. 2012), the effect of microhabitat soil

54 warming on early responses in many hardwood species is relatively understudied (but see

55 Rogiers et al. 2014, Štraus et al. 2015). Soil temperature may be particularly important at this

56 stage, as tree seedlings in their early life stage have very low growth forms; plants with low

57 growth forms may be more decoupled from atmospheric temperatures and more closely linked to

58 ground-level microclimates (Körner 2003). Information on individual seedling performance in warmer soils is thus needed to understand how predicted changes to soil microsite conditions can

60

61

1
affect the early life history stages of different hardwood tree species..

2

Acer rubrum (red maple) is a common canopy tree in the hardwood forests of the northeastern United States and Canada. This species can successfully germinate and grow under a broad range of microhabitat conditions: it occupies a wide germination niche, is relatively shade-tolerant and can exploit a variety of recruitment site conditions, particularly in disturbed litter and large canopy gaps (Rinkes and McCarthy 2007, Poznanovic et al. 2013). Acer rubrum seedlings are also strongly responsive to air temperature: spring seedling phenology accelerates with air warming (Kaye and Wagner 2014), and seedlings can also rapidly acclimate photosynthetic and respiration rates to air temperature changes (Lee et al. 2005, Sendall et al. 2015). This species has one of the widest distributions and broadest ecological amplitudes of any eastern deciduous forest species (Chapman and Bolen 2015), and is further becoming a dominant sub-canopy species in many forests in response to long-term fire suppression, land use changes, and curbing of competitors by deer browsing, defoliating insects and pathogens (Abrams 1998). Understanding how fine-scaled changes in soil temperature can affect growth and performance in first-year A. rubrum seedlings is critical to understand how this common tree species will 
76 respond to changing patterns of microhabitat conditions during its early life stages. Further, it

77 will help predict future patterns of microhabitats with optimal temperatures for $A$. rubrum

78 seedlings.

80 temperatures on the germination, leafing phenology, survival, growth, biomass accumulation and

81 biomass allocation in first-year A rubrum seedlings. Our study quantifies the effects of soil

82 temperature on the early life stages of $A$. rubrum and determine whether $A$. rubrum seedlings

83 growing in warmer soils demonstrate any tradeoffs in key performance traits.

84

85 METHODS

86

87 Site description

We set up our experiment in a lath house situated on a cleared meadow abutting mixed

89 hardwood stands at the Harvard Forest in Petersham MA, USA. A lath house is a wooden

90 structure composed of a series of narrow strips (laths), meant to protect young seedlings from

91 desiccation and herbivory. The lath house at Harvard Forest is $4.5 \mathrm{~m}$ tall and provides $50 \%$

92 shade. Concerning climate, the yearly average air temperature at the Fisher Meteorological

93 Station near the site (since 2001 ) is $8.1{ }^{\circ} \mathrm{C}$, with summer air temperatures averaging $17.4{ }^{\circ} \mathrm{C}$

94 (mean May-September). Total annual precipitation, including water equivalent of snow, averages

$951100 \mathrm{~mm}$ (Contosta et al. 2011).

96

97 Experimental setup 
In June 2015, we filled $8015.25 \mathrm{~cm}$ (6 inch diameter) pots with local soil sourced from

99 the edge of the forest ( $<20 \mathrm{~m}$ from our experimental site, an area occupied by mature $A$. rubrum).

100 We placed pots in dark plastic trays to standardize surface colour and drainage. There were two

101 levels of soil temperature treatment in this experiment: unheated (ambient temperature) control

102 pots, which we placed on bare dark gravel groundcover, and soil warming pots $\left(+5^{\circ} \mathrm{C}\right.$ above

103 ambient), which we placed on electric hydroponic heating mats (Root Radiance, China). We

104 randomly assigned pots to one of the two treatments. The pots were slightly shaded under a $3 \mathrm{~m}$

105 tall wooden lathe structure, but were situated close together (in a $2 \times 4 \mathrm{~m}$ area) in order to

106 minimize variation in light and other microscale environmental conditions. In addition, we

107 randomized pot position halfway through the growing season to minimize any effect of light

108 variation.

109

In the first week of June, we collected mature A. rubrum seeds in a single batch from a series of local A. rubrum trees (within $1 \mathrm{~km}$ of the experiment site). Acer rubrum germinates

112 immediately after maturation (Walters and Yawney 1990), so we planted seeds one day after

113 sampling. We planted six seeds in each pot (40 pots per treatment; total seed $\mathrm{N}=480$ ) and marked

114 the planted seeds with toothpicks to minimize the probability of counting an $A$. rubrum seed

115 already present in the soil or from an outside seedfall. Four weeks after planting, we thinned

116 germinants to one seedling per pot ( $\mathrm{N}=80$ seedlings) to eliminate the effects of intraspecific

117 competition on experimental seedling growth. We monitored pots daily or every other day

118 through the growing season, weeded as necessary to remove interspecific competitors and

119 watered to saturation when needed. 
121

122

123

124

125

126

127

128

129

130

131

132

133

134

135

136

137

138

139

140

141

142

143

\section{Field data collection}

After planting, we recorded day of onset of germination for each seed, in addition to total germination per pot (of six planted seeds). After germination, we recorded germinant survival over the first four weeks, and day of first true leaf expansion. Once per week until mid-August, we measured stem height, counted leaf number and measured the largest leaf area (leaf length $\times$ width) using calipers in order to determine the maximum number of leaves and the largest leaf size produced during the growing season. Since $A$. rubrum produces lobed leaves, our leaf measurements represent an approximation of individual leaf area. At the end of the growing season (early October), we measured total seedling height and stem diameter just above the root collar for each seedling using calipers. In early October, we also recorded leaf senescence on each seedling, where a seedling was defined as senescent if no green leaf tissue remained. In early November, we removed seedlings from pots and washed the roots to remove soil. We counted the number of branches from the main root, and measured the lengths of both the primary root and the longest secondary root using calipers. Root and stem tissues were then dried at $60^{\circ} \mathrm{C}$ for 72 hours. We removed any senescent leaf tissue, and then weighed stem tissue and root tissue separately using an analytic balance. We calculated root-stem ratios as root dry mass divided by stem dry mass.

We collected soil temperature data using a standard handheld soil probe at a depth of 5 $\mathrm{cm}$ in each pot containing experimental seedlings. We measured temperatures in a random sample of ten pots per treatment during each collection period. We collected temperature data daily during July to mid-August, and then every 2-3 days until late September. To verify that soil 
144 warming treatments were also effective at night, and across soil depths within the pots, we 145 measured soil temperatures at a depth of 7.5, 5 and $2.5 \mathrm{~cm}$ below soil surface at mid-day and 146 midnight within six pots containing no seedlings over a three-day period.

\section{Statistical analyses}

We used linear and general linear models using soil warming treatment as the explanatory variable to determine the effect of soil warming on phenology, survival, final size

152 and biomass allocation. When needed, we transformed response variables, and used residual 153 diagnostic plots when appropriate to confirm good model fit and normal residual distribution. To 154 examine growth responses over the course of the growing season, we used linear and general 155 linear mixed models, where treatment and number of days post-sowing were treated as fixed 156 effects, and plant identity was used as a random factor to address any issues of temporal 157 pseudoreplication. We report model error structures in Table 1. We performed all analyses using 158 R statistical software v. 3.1.2. (R Core Team 2014).

RESULTS

Temperature on ambient vs. soil warming treatments 
167 treatments during the growing season $(t=46.11, p<0.001$, Supplemental Figure 1$)$. Temperature 168 measurements taken at midnight over a three-day period showed night soil warming was 169 consistent with average daytime warming, with night mean soil temperatures of $19.4{ }^{\circ} \mathrm{C}$ at a 170 depth of $5 \mathrm{~cm}$ on soil warming treatment compared to $14.4{ }^{\circ} \mathrm{C}$ in control pots, for an average 171 night temperature difference of $5.0{ }^{\circ} \mathrm{C}$ (Supplemental Figure 2). The warming mats significantly 172 raised soil temperatures by $2.97,4.49$ and $6.1^{\circ} \mathrm{C}{ }^{\circ}$ relative to the control pots at the surface, 173 middle, and deepest soil layers, respectively $(t=5.77, p<0.001 ; t=8.79, p<0.001 ; t=12.81$, $174 p<0.001)$. Supplemental Figure 3 shows temperatures at soil surface, $5 \mathrm{~cm}$ and $7.5 \mathrm{~cm}$ below soil 175 surface measured at mid-day and midnight over a three-day period.

176

177 Germination, germinant and seedling survival

Overall germination was relatively high, with a minimum of one seed germinating in all 180 pots, and $63 \%$ of all seeds germinating. Seed germination was similar between control and soil 181 warming treatments, with no significant effect of warming (Table 1). Survival after germination 182 was very high; $98 \%$ of seedlings survived to the thinning stage. Soil warming also had no 183 significant effect on germinant survival in the first four weeks (prior to thinning; Table 1).

184 Seedling survival after thinning was uniformly high and unaffected by soil warming treatment, 185 with $97 \%$ of seedlings in control treatments and $95 \%$ of seedlings in soil warming treatments 186 surviving during the first growing season. 
Onset of germination occurred 9 days after sowing for both treatments, with the last new

191

192

193

194

195

196

197

198

199

200

201

202

203

204

205

206

207

208

209

210

211

212

germination occurring 21 days after sowing. Germination onset was similar on controls and soil

warming treatments (control mean germination onset $=12.5$ days post-sowing, $\mathrm{SE}=0.36$; soil warming mean germination onset $=12.4$ days post-sowing, $\mathrm{SE}=0.44$; Table 1 ). Onset of leaf expansion began 13 days after sowing, and occurred significantly earlier under soil warming treatments relative to controls (control mean leaf expansion onset $=15.5$ days post-sowing, soil warming mean leaf expansion onset $=14.4$ days post-sowing; Table 1 ). The day of peak leaf production (day post-sowing after which seedlings did not produce significantly more leaves) occurred later under soil warming treatments (control mean peak leaf production $=55$ days postsowing, soil warming peak leaf production = 93 days post-sowing; Figure 1A). By early October (118 days post-sowing), leaf senescence was more likely to have occurred for seedlings in control treatments relative to seedlings in soil warming treatments (Table 1). By early October, $74 \%$ of control seedlings were fully senescent, compared to $11 \%$ on soil warming treatment.

\section{Growth responses}

Soil warming had a significant and positive effect on aboveground structure size. At the end of the growing season (early October, 118 days post-sowing), seedlings were significantly taller on soil warming treatment $($ mean height $=83.1 \mathrm{~mm})$ relative to controls $($ mean height $=$ $61.1 \mathrm{~mm}$; Table 1; Figure 2A). Final stem diameter just above the root collar was larger for seedlings on soil warming treatments (mean stem diameter $=2.74 \mathrm{~mm}$ ) relative to controls (mean stem diameter $=1.82 \mathrm{~mm}$; Table 1; Figure 2B). Final stem dry mass was significantly higher on soil warming treatments (mean dry wood mass $=99.95 \mathrm{mg}$ ) relative to controls (mean dry wood 
213 mass $=39.73 \mathrm{mg}$; Table 1; Figure 2C). At peak leaf production, maximum leaf number was

214 significantly higher on soil warming treatment (mean leaf $\mathrm{N}=11.8$ ) relative to controls (mean

215 leaf $\mathrm{N}=5.8$; Table 1; Figure 2D). Similarly, mean largest leaf area was higher on soil warming

216 treatment (mean leaf area $=985 \mathrm{~mm}^{2}$ ) relative to controls (mean leaf area $=462 \mathrm{~mm}^{2}$; Table 1 ;

217 Figure 2E).

218

219

Stem height, leaf number, and leaf area also significantly varied as a function of soil

220 warming treatment, time post-sowing, and the interaction between both factors (Table 2). Leaf

221 number was the first growth trait to respond to soil warming, followed by stem height and last by

222 leaf area. Leaf number was similar between treatments, although somewhat higher on soil

223 warming treatments, until 55 days post-sowing (late July), after which seedlings on soil warming

224 treatments consistently demonstrated significantly higher leaf numbers (Figure 1A). After 55

225 days post-sowing, control seedlings no longer produced new leaves (leaf number did not

226 significantly increase), while seedlings in soil warming treatments continued to produce new

227 leaves until the last leaf count at 93 days post-sowing, an increase in new leaf production of 38

228 days (Figure 1A). Stem height was similar between treatments until 69 days post-sowing (mid-

229 August), after which seedlings on soil warming treatments demonstrated significantly taller

230 stems (Figure 1B). After 62 days post-sowing, control seedling stem height did not significantly

231 increase, while seedlings on soil warming treatments continued to grow until 93 days post-

232 sowing, an increase in stem elongation time of 24 days (Figure 1B). Mean largest leaf area was

233 similar between treatments until the last leaf measurement period 93 days post-sowing (early

234 September), at which point seedlings on soil warming treatments showed significantly larger 
235 leaves (Figure 1C). Model results for differences in leaf number, mean largest leaf area and stem

236 height between treatments for each measurement period are reported in Supplemental Table 1.

238 Root size and root-stem ratios

239

Soil warming also had a strongly significant positive effect on belowground biomass.

241 While number of main root branches was similar in both treatments (control mean $\mathrm{N}$

242 branches $=9.3$, soil warming mean $\mathrm{N}$ branches $=10.4$; Table1, Figure $3 \mathrm{~A}$ ), soil warming

243 significantly influenced root lengths and dry mass. Soil warming had a weakly significant

244 positive effect on the length of the main root (control mean length $=39.3 \mathrm{~mm}$, soil warming mean

245 length $=53.0$; Table 1, Figure 3B). Soil warming had a stronger positive effect on secondary root

246 length (control mean length=51.6 mm, warming mean length $=118.6 \mathrm{~mm}$; Table 1, Figure $3 \mathrm{C}$ ).

247 Root dry mass was significantly higher on the soil warming treatment (mean dry root mass $=$

$248198.40 \mathrm{mg}$ ) relative to controls (mean dry root mass $=41.56 \mathrm{mg}$; Table 1 , Figure 3D). Soil

249 warming also significantly influenced biomass allocation. Seedlings grown in the soil warming

250 treatment demonstrated significantly higher allocation to root biomass over stem biomass (mean

251 root-stem ratio $=2.057)$ relative to controls $($ mean root-stem ratio $=1.024$; Table 1$)$.

\section{DISCUSSION}

Our findings suggest that warmer soils positively affect the performance and potential

255 recruitment of first year red maple seedlings, as evidenced by taller, thicker $A$. rubrum seedlings

256 with larger root systems in our $+5^{\circ} \mathrm{C}$ soil warming treatment. Our phenological and growth data

257 suggest that the mechanism driving this response is an increase in the duration of the active 
258 growth period. Earlier leaf expansion and later leaf retention led to a longer active leaf

259 production period, larger leaves and a longer stem elongation period, leading to increased final

260 height, stem thickness and stem and root biomass accumulation. Biomass allocation to roots was

261 also higher under soil warming, although this did not indicate an allocation tradeoff, as stem

262 biomass accumulation also significantly increased under soil warming. Below we discuss these

263 findings in more detail, along with implications for future recruitment of $A$. rubrum.

264

\section{Extended leaf retention and production period}

266 Leaf expansion and leaf senescence are two key factors controlling carbon acquisition in

267 deciduous trees, as they control initiation and end of the photosynthetically-active growing

268 season. Our results show that soil warming led to slightly earlier leaf expansion and later leaf

269 retention in fall. These results are similar to other studies examining atmospheric warming and $A$.

270 rubrum seedling phenology; Norby et al. (2003) showed that warmer air temperature accelerated

271 bud break, and delayed leaf abscission, and Kaye and Wagner (2014) found earlier leaf

272 expansion with air warming. We found soil temperature did not influence germination timing,

273 likely because $A$. rubrum has no environmental requirements for germination and predominantly

274 germinates rapidly after seed maturation (Abbott 1974). Interestingly, soil warming significantly

275 extends the active leaf production periods for $A$. rubrum seedlings later in the growing season, as

276 control seedlings set buds and stopped producing new leaves in late July, whereas seedlings

277 grown in the soil warming treatment continued to produce new leaves until early September.

278 This is likely one factor accounting for the differences in size and biomass accumulation between

279 treatments. Soolanayakanahally et al. (2013) demonstrated that earlier bud set was associated

280 with reduced height in Populus balsamifera, and there was a strong correlation between longer 
281 leaf retention and stem growth in Populus trichocarpa (Dunlap and Stettler 1998). We suggest

282 soil warming most strongly affects $A$. rubrum seedlings later in the growing season, through the

283 extended leaf production period and later leaf retention, and the effect of soil warming on leaf

284 phenology and production period directly affects growth and biomass accumulation patterns.

285

286

Positive growth and biomass allocation responses to soil warming

287

We observed positive effects of soil warming on growth both above- and belowground

288

for $A$. rubrum seedlings, a result that contrasts with other studies examining soil or air warming,

289

which generally demonstrated either neutral, negative or mixed effects of warming on growth in

290

Acer seedlings and saplings. Farnsworth et al. (1995) found no effect of soil warming on leaf size

in A. rubrum saplings, while Rogiers et al. (2014) found root-zone soil warming increased leaf

292

biomass and root size, but not height in A. negundo seedlings. Carón et al. (2015) found soil

293 warming reduced both above and belowground biomass in $A$. platanoides and $A$.

294

pseudoplantanus seedlings, and Norby and Luo (2004) showed smaller aboveground woody dry

295

mass accumulation after four years of air warming treatments in A. rubrum and A. saccharum

296 saplings. Most studies that found no or negative effects of soil or air warming on $A$. rubrum

297 examined older saplings; however, similarly to our results, Butler et al. (2012) showed soil

298 warming increased relative growth rate in older, larger $A$. rubrum $(>5 \mathrm{~cm} \mathrm{DBH})$. Our results

299 contribute further evidence that growth responses to air and soil warming may be highly species-

300 dependent in Acer species. Further, growth responses to warming may be contingent on life

301 stage. Other environmental conditions may interact with warming to affect seedling

302 performance. For example, in Norby and Luo (2004), relative growth rates in $A$. rubrum were

303 only depressed by air warming in one of the four years in that study, highlighting the role of 
304 stochastic events such as spring frost altering normal phenology and severe heat waves causing

305 heat stress. We watered our experimental pots to saturation as needed, so the seedlings were not

306 water-limited, and the soil temperature record shows no extreme cold events during the course of

307 the experiment. Thus our results suggest that in the absence of extreme drought or frost events,

308 A. rubrum responds positively to soil warming on its own, and that seedlings in microsites with

309 warmer soils will have greater biomass accumulation both above and belowground, at least in the

310 first year of growth.

Root mass differences under soil warming were likely a factor driving the observed differences in growth and seedling size. Root biomass in tree seedlings generally increases with

314 soil and air warming to species optima (Pregitzer et al. 2000, Yuan and Chen 2010). For $A$.

315 rubrum specifically, Wan et al. (2004) showed air warming increased fine root production and

316 turnover in seedlings in the short term. The larger root systems in the soil warming treatment

317 likely absorbed more nutrients and water from the soil, stimulating aboveground growth. The

318 increase in leaf number, leaf size and active leaf production period in seedlings grown in warmer

319 soils likely also increased carbon acquisition, although we did not measure non-structural

320 carbohydrates. The larger sizes and masses of seedlings grown under soil warming are also likely

321 driven by the rapid response of metabolic processes in A. rubrum to changes in temperature. Lee

322 et al. (2005) demonstrated that young (3-year old) A. rubrum can rapidly acclimate leaf

323 respiration rates to warmer air temperatures and Sendall et al. (2015) demonstrated that $A$.

324 rubrum seedlings also rapidly acclimate photosynthetic responses to warmer air temperatures.

325 Although we did not measure metabolic rates, our results suggest these patterns of respiration

326 and photosynthetic responses may too be characteristic to first-year $A$. rubrum under soil 
327 warming conditions, contributing to the observed differences in growth and biomass

328 accumulation.

Implications of soil warming for Acer rubrum recruitment

The availability and suitability of small-scale microhabitats can strongly control seedling recruitment, particularly when seedfall is not limited. For some species, conditions affecting recruitment can change rapidly with increasing variability in climate conditions between years

334 (Perez-Ramos et al. 2013), and in the long-term, climate change could alter the pattern of 335 suitable microhabitat at the landscape scale. As A. rubrum is generally considered a relatively 336 fecund species (Beckage and Clarke 2003), suitable microhabitat availability, and changes in 337 microhabitat conditions may become increasingly important for future recruitment. With atmospheric warming under climate change, soil temperatures are increasing across a range of

339 ecosystem types (Qian et al. 2011, Ooi et al. 2012). Further, increases in other landscape-level 340 disturbances, such as treefalls (Peterson et al. 1990), canopy gaps (Yuan-Bin et al. 2006) and 341 edge effects (Redding et al. 2003) can increase the availability of warm soil microsites in forests 342 and thereby benefit seedling performance and subsequent recruitment of $A$. rubrum.

Although our study examined the effects of soil warming in the first season, our results suggest that short-term as well as sustained periods of warmer soils can have implications for

346 long-term A. rubrum survival and recruitment. Canham et al. (1999) showed roots functioned as

347 the main carbon storage sink in A. rubrum seedlings, and that seedlings with higher carbon

348 reserves demonstrated higher overwinter survival. Low growth rates over multiple seasons are 349 strongly linked to mortality in A. rubrum (Wyckoff and Clark 2002), whereas larger, sturdier 
350 seedlings are likely more resistant to mechanical damage from animal trampling (Newman and

351 Powell 1997). Larger stem and root sizes could further confer competitive advantages in the

352 following growing seasons, particularly as A. rubrum is a relatively weak competitor with other

353 tree seedlings (Beckage and Clarke 2003). Thus, the positive effects of warmer soils in the first

354 year could extend to recruitment success in the first few years of the seedling life stage.

The limitations of this study include that this is a potted plant experiment, with soil

357 warming initiated from below, as opposed to soil warming driven by higher atmospheric

358 warming; further, we could not reasonably measure a multitude of possible interactions with the

359 biotic and abiotic environment. . For example, photosynthesis is stimulated up to a threshold, 360 beyond which heat stress and drought can reduce carbon sequestration (Ciais et al. 2005). Other

361 factors, such as early frosts, could also negatively impact $A$. rubrum when the growing season is 362 prolonged under soil warming conditions (Norby et al. 2003). Soil warming may also affect 363 arbuscular mycorrhizal fungi colonization (Rillig et al. 2002), and potential interactions with 364 competitors and natural enemies (Landhausser and Lieffers 1998, Dukes et al. 2009). However, 365 even if we conservatively estimate that soil warming augments biomass accumulation and 366 growing period only in the first summer, our results suggest that A. rubrum will perform better as 367 microsites with warmer soils become increasingly abundant, through the production of larger, 368 studier structures in the first season, with no evident tradeoffs in biomass allocation above and 369 belowground.

370

371 Acknowledgements 
372 We would like to thank L. Hancock, W. De Vore, C. Drakakis, and S. Gerdes for assistance in

373 the field and in processing samples, J. Albertine and D. Haines for valuable discussions about the

374 manuscript, and several anonymous reviewers and an associate editor for helpful commentary.

375 We also thank the Harvard Forest for providing logistic support during this study. Funding for

376 JW and KS provided by the United States Strategic Environmental Research and Development

377 Program, and by the NSF Research Experiences for Undergraduates Program through the

378 Harvard Forest for NG. The authors declare they have no conflicts of interest.

\section{REFERENCES}

379 IPCC, 2013: Climate Change 2013: The Physical Science Basis. Contribution of Working Group

380 I to the Fifth Assessment Report of the Intergovernmental Panel on Climate Change [Stocker,

381 T.F., D. Qin, G.-K. Plattner, M. Tignor, S.K. Allen, J. Boschung, A. Nauels, Y. Xia, V. Bex and

382 P.M. Midgley (eds.)]. Cambridge University Press, Cambridge, United Kingdom and New York, $383 \quad \mathrm{NY}, \mathrm{USA}, 1535 \mathrm{pp}$

Abbott, H.G. 1974. Some characteristics of fruitfulness and seed germination in red maple. Tree Planters' Notes 25: 25-27.

Abrams, M.D. 1998. The Red Maple Paradox. Bioscience 48: 355-364.

Beckage, B., and Clark, J.S. 2003. Seedling survival and growth of three forest tree species: The role of spatial heterogeneity. Ecology 84: 1849-1861.

Butler, S.M., Melillo, J.M., Johnson, J.E., Mohan, J., Steudler, P.A., Lux, H., Burrows, E., Smith, R.M., Vario, C.L., Scott, L., Hill, T.D., Aponte, N., and Bowles, F. 2012. Soil warming 
alters nitrogen cycling in a New England forest: implications for ecosystem function and structure. Oecologia 168: 819-828.

Caldeira, M.C., Ibanez, I., Nogueira, C., Bugalho, M.N., Lecomte, X., Moreira, A., and Pereira, J.S. 2014. Direct and indirect effects of tree canopy facilitation in the recruitment of Mediterranean oaks. J. Appl. Ecol. 51: 349-358.

Canham, C.D., Kobe, R.K., Latty, E.F., and Chazdon, R.L. 1999. Interspecific and intraspecific variation in tree seedling survival: effects of allocation to roots versus carbohydrate reserves. Oecologia 121: 1-11.

Carón, M.M., De Frenne, P., Chabrerie, O., Cousins, S.A.O., De Backer, L., Decocq, G., Diekmann, M., Heinken, T., Kolb, A., Naaf, T., Plue, J., Selvi, F., Strimbeck, G.R., Wulf, M., and Verheyen, K. 2015. Impacts of warming and changes in precipitation frequency on the regeneration of two Acer species. Flora - Morphology, Distribution, Functional Ecology of Plants 214: 24-33.

Castro, J., Allen, C.D., Molina-Morales, M., Maranon-Jimenez, S., Sanchez-Miranda, A., and Zamora, R. 2011. Salvage logging versus the use of burnt wood as a nurse object to promote post-fire tree seedling establishment. Restor. Ecol. 19: 537-544.

Chapman, B.R., and Bolen, E.G. - Ecology of North America, $2^{\text {nd }}$ Ed. Wiley-Blackwell, West Sussex, UK

Ciais, P., Reichstein, M., Viovy, N., Granier, A., Ogee, J., Allard, V., Aubinet, M., Buchmann, N., Bernhofer, C., Carrara, A., Chevallier, F., De Noblet, N., Friend, A.D., Friedlingstein, P., 
Grunwald, T., Heinesch, B., Keronen, P., Knohl, A., Krinner, G., Loustau, D., Manca, G., Matteucci, G., Miglietta, F., Ourcival, J.M., Papale, D., Pilegaard, K., Rambal, S., Seufert, G., Soussana, J.F., Sanz, M.J., Schulze, E.D., Vesala, T., and Valentini, R. 2005. Europe-wide reduction in primary productivity caused by the heat and drought in 2003. Nature 437: 529-533.

Contosta, A.R., Frey, S.D., Cooper, A.B. 2011. Seasonal dynamics of soil respiration and N mineralization in chronically warmed and fertilized soils. Ecoscience 2:

Danyagri, G., and Dang, Q. 2014. Effects of elevated carbon dioxide concentration and soil temperature on the growth and biomass responses of mountain maple (Acer spicatum) seedlings to light availability. Journal of Plant Ecology 7: 535-543.

Dukes, J.S., Pontius, J., Orwig, D., Garnas, J.R., Rodgers, V.L., Brazee, N., Cooke, B., Theoharides, K.A., Stange, E.E., Harrington, R., Ehrenfeld, J., Gurevitch, J., Lerdau, M., Stinson, K., Wick, R., and Ayres, M. 2009. Responses of insect pests, pathogens, and invasive plant species to climate change in the forests of northeastern North America: What can we predict? Can. J. For. Res. -Rev. Can. Rech. For. 39: 231-248.

Dunlap, J.M., and Stettler, R.F. 1998. Genetic variation and productivity of Populus trichocarpa and its hybrids. X. Trait correlations in young black cottonwood from four river valleys in Washington. Trees-Structure and Function 13: 28-39.

Farnsworth, E., Nunez-Farfan, J., Careaga, S., and Bazzaz, F. 1995. Phenology and growth of three temperate forest life forms in response to artificial soil warming. J. Ecol. 83: 967-977. 
Frey, S.D., Lee, J., Melillo, J.M., and Six, J. 2013. The temperature response of soil microbial efficiency and its feedback to climate. Nature Clim. Change 3: 395-398.

Harper, J.L. 1977. Population Biology of Plants. Academic Press, London; New York.

Kaye, M.W., and Wagner, R.J. 2014. Eastern deciduous tree seedlings advance spring phenology in response to experimental warming, but not wetting, treatments. Plant Ecol. 215: 543-554.

Körner, C. 2003. Alpine Plant Life: Functional Plant Ecology of High Mountain Ecosystems. Springer, Heidelberg, Germany.

Landhausser, S., and Lieffers, V. 1998. Growth of Populus tromuloides in association with Calamagrostis canadensis. Can. J. For. Res. -Rev. Can. Rech. For. 28: 396-401.

Lee, T.D., Reich, P.B., and Bolstad, P.V. 2005. Acclimation of leaf respiration to temperature is rapid and related to specific leaf area, soluble sugars and leaf nitrogen across three temperate deciduous tree species. Funct. Ecol. 19: 640-647.

Newman, R.F., Powell, G.W. 1997. Forest grazing: effects of cattle trampling and browsing on lodgepole pine plantations. B.C. Min. For. Ext. Note 13:

Norby, R.J., and Luo, Y.Q. 2004. Evaluating ecosystem responses to rising atmospheric CO(2) and global warming in a multi-factor world. New Phytol. 162: 281-293.

Norby, R.J., Hartz-Rubin, J.S., and Verbrugge, M.J. 2003. Phenological responses in maple to experimental atmospheric warming and CO2 enrichment. Global Change Biol. 9: 1792-1801. 
Ooi, M.K.J., Auld, T.D., and Denham, A.J. 2012. Projected soil temperature increase and seed dormancy response along an altitudinal gradient: implications for seed bank persistence under climate change. Plant Soil 353:289-303.

Perez-Ramos, I.M., Rodriguez-Calcerrada, J., Ourcival, J.M., and Rambal, S. 2013. Quercus ilex recruitment in a drier world: A multi-stage demographic approach. Perspectives in Plant Ecology Evolution and Systematics 15:106-117.

Peterson, C., Carson, W., McCarthy, B., and Pickett, S. 1990. Microsite variation and soil dynamics within newly created treefall pits and mounds. Oikos 58: 39-46.

Poznanovic, S.K., Webster, C.R., and Bump, J.K. 2013. Maintaining mid-tolerant tree species with uneven-aged forest management: 9-year results from a novel group-selection experiment. Forestry 86: 555-567.

Pregitzer, K.S., Zak, D.R., Maziasz, J., DeForest, J., Curtis, P.S., and Lussenhop, J. 2000. Interactive effects of atmospheric $\mathrm{CO} 2$ and soil-N availability on fine roots of Populus tremuloides. Ecol. Appl. 10: 18-33.

Qian, B., Gregorich, E.G., Gameda, S., Hopkins, D.W., and Wang, X.L. 2011. Observed soil temperature trends associated with climate change in Canada. Journal of Geophysical Research: Atmospheres 116:

R Core Team (2014). R: A language and environment for statistical computing. R Foundation for Statistical Computing, Vienna, Austria. URL http://www.R-project.org/. 
Redding, T.E., Hope, G.D., Fortin, M.J., Schmidt, M.G., and Bailey, W.G. 2003. Spatial patterns of soil temperature and moisture across subalpine forest-clearcut edges in the southern interior of British Columbia. Can. J. Soil Sci. 83: 121-130.

Rillig, M.C., Wright, S.F., Shaw, M.R., and Field, C.B. 2002. Artificial climate warming positively affects arbuscular mycorrhizae but decreases soil aggregate water stability in an annual grassland. Oikos 97: 52-58.

Rinkes, Z.L., and McCarthy, B.C. 2007. Ground layer heterogeneity and hardwood regeneration in mixed oak forest. Applied Vegetation Science 10: 279-284.

Rogiers, S.Y., Smith, J.P., Holzapfel, B.P., and Nielsen, G.L. 2014. Shifts in biomass and nitrogen allocation of tree seedlings in response to root-zone temperature. Aust. J. Bot. 62: 205216.

Schmidt, M.G., Ogden, A.E., and Lertzman, K.P. 1998. Seasonal comparison of soil temperature and moisture in pits and mounds under vine maple gaps and conifer canopy in a coastal western hemlock forest. Can. J. Soil Sci.78: 291-300.

Searle, S.Y., Turnbull, M.H., Boelman, N.T., Schuster, W.S.F., Yakir, D., and Griffin, K.L. 2012. Urban environment of New York City promotes growth in northern red oak seedlings. Tree Physiology 32: 389-400.

Sendall, K.M., Reich, P.B., Zhao, C., Hou Jihua, Wei, X., Stefanski, A., Rice, K., Rich, R.L., and Montgomery, R.A. 2015. Acclimation of photosynthetic temperature optima of temperate and 
boreal tree species in response to experimental forest warming. Global Change Biol. 21: 13421357.

Soolanayakanahally, R.Y., Guy, R.D., Silim, S.N., and Song, M. 2013. Timing of photoperiodic competency causes phenological mismatch in balsam poplar (Populus balsamifera L.). Plant Cell and Environment 36: 116-127.

Štraus, I., Mrak, T., Ferlan, M., Zeleznik, P., and Kraigher, H. 2015. Influence of soil temperature on growth traits of European beech seedlings. Canadian Journal of Forest Research 45: 246-251.

Thompson, L.J., and Naeem, S. 1996. The effects of soil warming on plant recruitment. Plant Soil 182: 339-343.

Utsugi, E., Kanno, H., Ueno, N., Tomita, M., Saitoh, T., Kimura, M., Kanou, K., and Seiwa, K. 2006. Hardwood recruitment into conifer plantations in Japan: Effects of thinning and distance from neighboring hardwood forests. For. Ecol. Manage. 237: 15-28.

Walters, R.S., and Yawney, H.W. 1990. Acer rubrum L., red maple. P. 60- 69 in Silvics of North America, Vol. 2, Hardwoods, Bums, R.M., and B.H. Honkala (eds.). USDA For. Serv. Agric. Handb. No. 654, US Gov. Print. Off., Washington, D.C.

Wan, S., Norby, R.J., Pregitzer, K.S., Ledford, J., and O'Neill, E.G. 2004. CO2 enrichment and warming of the atmosphere enhance both productivity and mortality of maple tree fine roots. New Phytol. 162: 437-446. 
Wertin, T.M., McGuire, M.A., and Teskey, R.O. 2011. Higher growth temperatures decreased net carbon assimilation and biomass accumulation of northern red oak seedlings near the southern limit of the species range. Tree Physiol. 31: 1277-1288.

Wyckoff, P.H., and Clark, J.S. 2002. The relationship between growth and mortality for seven co-occurring tree species in the southern Appalachian Mountains. J. Ecol. 90: 604-615.

Yuan, Z.Y., and Chen, H.Y.H. 2010. Fine root biomass, production, turnover rates, and nutrient contents in boreal forest ecosystems in relation to species, climate, fertility, and stand age: literature review and meta-analyses. Crit. Rev. Plant Sci. 29: 204-221.

Zhang Yuan-Bin, Wang Kai-Yun, and Xian Jun-Ren. 2006. Microenvironment of forest gaps and its effects on the growth of naturally regenerated seedlings of different ages in subalpine Abies faxoniana forest. Zhiwu Shengtai Xuebao 30: 941-946. 
Table 1: Germination, phenology, size, and biomass allocation in Acer rubrum (red maple;

$\mathrm{N}=80$ ) seedling under a $5^{\circ} \mathrm{C}$ soil warming treatment during the 2015 growing season at the

Harvard Forest in Petersham, MA, USA. The data are from linear and general linear models.

Error structure used for each model is listed, as are t- or z-values and p-values (asterisks shown

when significant).

\begin{tabular}{|llll|}
\hline Response & Model error structure & Effect of soil warming \\
\hline Germination proportion & Binomial & $z=-1.47$ & $p=0.14$ \\
\hline Germinant survival proportion & Binomial & $z=-0.009$ & $p=0.99$ \\
\hline Onset of germination & Gamma & $t=0.28$ & $p=0.78$ \\
\hline Onset of leaf expansion & Gamma & $t=3.09$ & $p=0.0028^{*}$ \\
\hline Leaf senescence in October & Binomial & $z=-4.98$ & $p<0.001^{*}$ \\
\hline Final seedling height $(\mathrm{mm})$ & Gaussian & $t=5.30$ & $p<0.001^{*}$ \\
\hline Final stem diameter $(\mathrm{mm})$ & Gaussian & $t=9.72$ & $p<0.001^{*}$ \\
\hline Maximum leaf N & Poisson & $z=13.65$ & $p<0.001^{*}$ \\
\hline Largest leaf area $\left(\mathrm{mm}^{2}\right)$ & Gaussian & $t=6.03$ & $p<0.001^{*}$ \\
\hline Final stem dry mass $(\mathrm{mg})$ & Gaussian & $t=6.02$ & $p<0.001^{*}$ \\
\hline N main root branches & Poisson & $z=1.53$ & $p=0.13$ \\
\hline Main root length $(\mathrm{mm})$ & Gaussian & $t=2.72$ & $p=0.0074^{*}$ \\
\hline Secondary root length $(\mathrm{mm})$ & Gaussian & $t=8.76$ & $p<0.001^{*}$ \\
\hline Root dry mass $(\mathrm{mg})$ & Gaussian & $t=8.86$ & $p<0.001^{*}$ \\
\hline Root:stem ratio & Gaussian & $t=7.87$ & $p<0.001^{*}$ \\
\hline
\end{tabular}


Table 2: Acer rubrum (red maple; $\mathrm{N}=80)$ growth responses to soil warming $\left(5^{\circ} \mathrm{C}\right)$ over time during the 2015 growing season at the Harvard Forest in Petersham, MA, USA. The data are from linear and general linear models. Error structure used for each model is listed, as are t- or zvalues and p-values (asterisks shown when significant).

\begin{tabular}{|l|l|l|l|l|}
\hline Response & $\begin{array}{l}\text { Model error } \\
\text { structure }\end{array}$ & Soil warming & $\begin{array}{l}\text { N days post-sowing } \\
\text { (time) }\end{array}$ & $\begin{array}{l}\text { Soil warming * } \\
\text { time }\end{array}$ \\
\hline $\begin{array}{l}\text { Seedling height } \\
(\mathrm{mm})\end{array}$ & Gaussian & $\begin{array}{l}t=2.62 \\
p=0.011^{*}\end{array}$ & $\begin{array}{l}t=11.43 \\
p<0.001^{*}\end{array}$ & $\begin{array}{l}t=11.93 \\
p<0.001^{*}\end{array}$ \\
\hline Mean largest leaf & Gaussian & $t=4.98$ & $t=4.09$ & $t=10.37$ \\
area & & $p<0.001^{*}$ & $p<0.001^{*}$ & $p<0.001^{*}$ \\
\hline N leaf & Poisson & $\mathrm{z}=10.90$ & $\mathrm{z}=5.99$ & $\mathrm{z}=4.93$ \\
& & $p<0.001^{*}$ & $p<0.001^{*}$ & $p<0.001^{*}$ \\
\hline
\end{tabular}




\section{FIGURE TITLES}

Figure 1: Acer rubrum (red maple; $\mathrm{N}=80$ ) mean stem height (A), leaf number (B), and largest leaf area (C) under ambient (white points) and $5^{\circ} \mathrm{C}$ soil warming (grey points) treatments during the first growing season after sowing. Note different scales on the y-axes. Error bars are used to denote standard error (SE).

Figure 2: Acer rubrum (red maple; N=80) A) seedling height at the end of the growing season, B) stem diameter at base at the end of the growing season, C) stem dry mass at the end of the growing season, D) maximum leaf number produced and E) largest leaf area under ambient (white bars) and $5^{\circ} \mathrm{C}$ soil warming (grey bars) treatments during the 2015 growing season at the Harvard Forest in Petersham, MA, USA. Note different scales on the y-axes. Error bars are used to denote standard error (SE).

Figure 3: Acer rubrum (red maple; $\mathrm{N}=80$ ) root structure, with A) number of branches on the main root, B) length of main root, C) longest secondary root length and D) root dry mass at the end of the growing season under ambient (white bars) and $5^{\circ} \mathrm{C}$ soil warming (grey bars) treatments at the Harvard Forest in Petersham, MA, USA. Note different scales on the y-axes. Error bars are used to denote standard error (SE). 

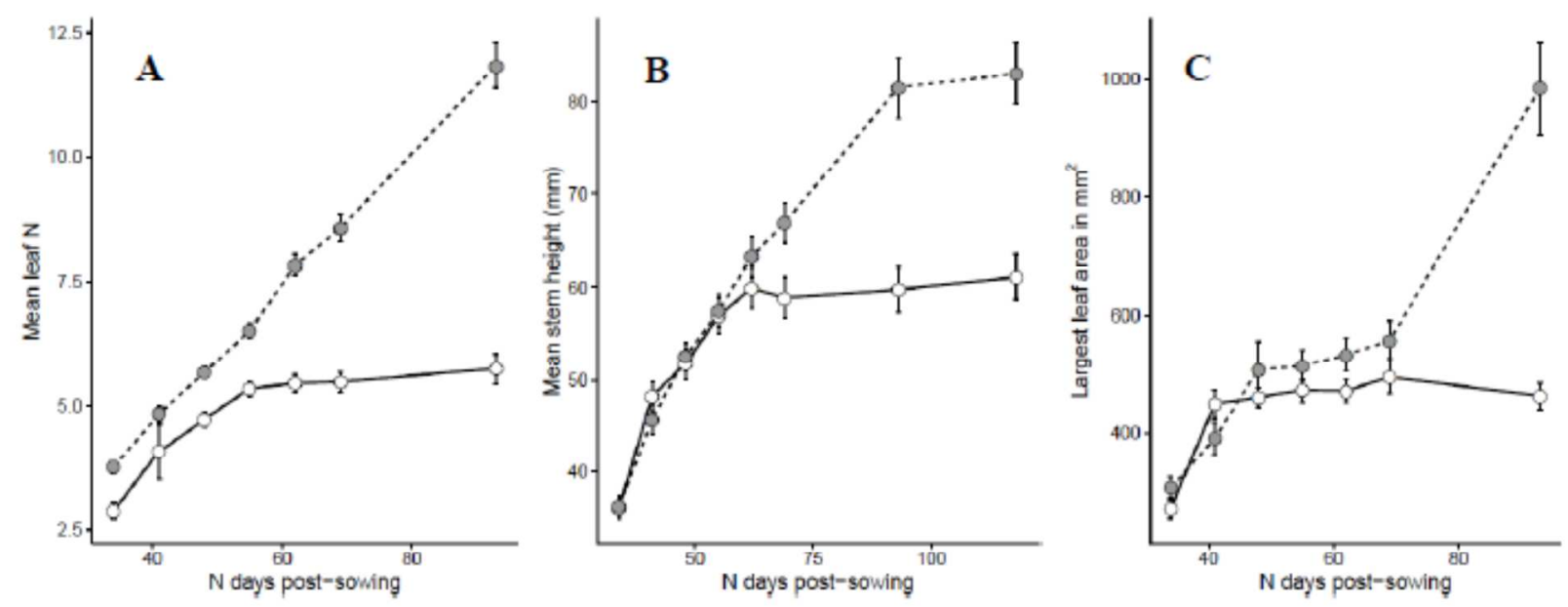

Figure 1 

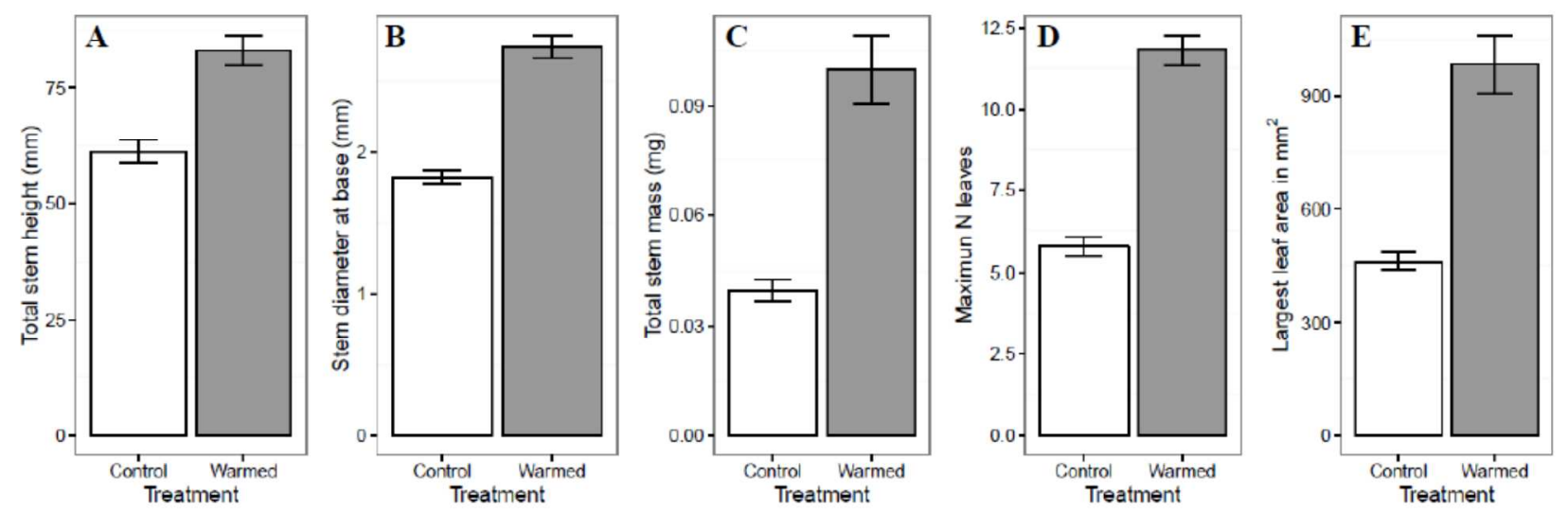

Figure 2 

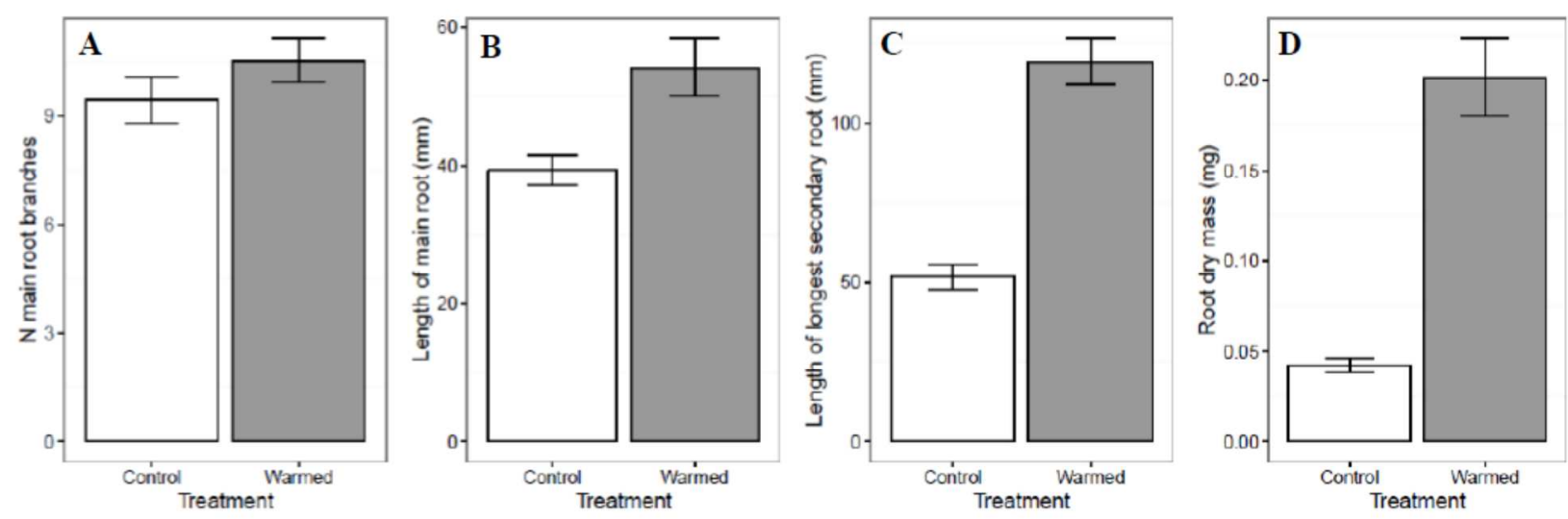

Figure 3 
Supplemental Material

Table S1: Acer rubrum (red maple; $\mathrm{N}=80$ ) growth responses to soil warming $\left(5^{\circ} \mathrm{C}\right)$ at eight time points after sowing. Model error structures are indicated in parentheses. Significant $t / z$ and pvalues are bolded.

\begin{tabular}{|c|c|c|}
\hline Response & $\mathrm{N}$ days post-sowing & Soil warming \\
\hline \multirow{8}{*}{$\begin{array}{l}\text { Plant height } \\
\text { (Gaussian) }\end{array}$} & 34 & $t=0.12, p=0.90$ \\
\hline & 41 & $t=-1.15, p=0.26$ \\
\hline & 48 & $t=0.34, p=0.74$ \\
\hline & 55 & $t=0.21, p=0.81$ \\
\hline & 62 & $t=1.09, p=0.28$ \\
\hline & 69 & $t=2.60, p=0.011$ \\
\hline & 93 & $t=5.31, p<0.001$ \\
\hline & 118 & $t=5.30, p<0.001$ \\
\hline \multirow{7}{*}{$\begin{array}{l}\text { Leaf number } \\
\text { (Poisson) }\end{array}$} & 34 & $\mathrm{z}=2.14, p=0.031$ \\
\hline & 41 & $\mathrm{z}=1.60, p=1.11$ \\
\hline & 48 & $\mathrm{z}=1.86, p=0.065$ \\
\hline & 55 & $\mathrm{z}=2.13, p=0.033$ \\
\hline & 62 & $\mathrm{z}=3.99, p<0.001$ \\
\hline & 69 & $\mathrm{z}=5.04, p<0.001$ \\
\hline & 93 & $\mathrm{z}=8.78, p<0.001$ \\
\hline \multirow{7}{*}{$\begin{array}{l}\text { Mean leaf area } \\
\text { (Gaussian) }\end{array}$} & 34 & $t=1.26, p=0.21$ \\
\hline & 41 & $t=-1.59, p=0.12$ \\
\hline & 48 & $t=1.00, p=0.32$ \\
\hline & 55 & $t=1.31, p=0.20$ \\
\hline & 62 & $t=1.85, p=0.070$ \\
\hline & 69 & $t=1.43, p=0.16$ \\
\hline & 93 & $t=6.50, p<0.001$ \\
\hline
\end{tabular}




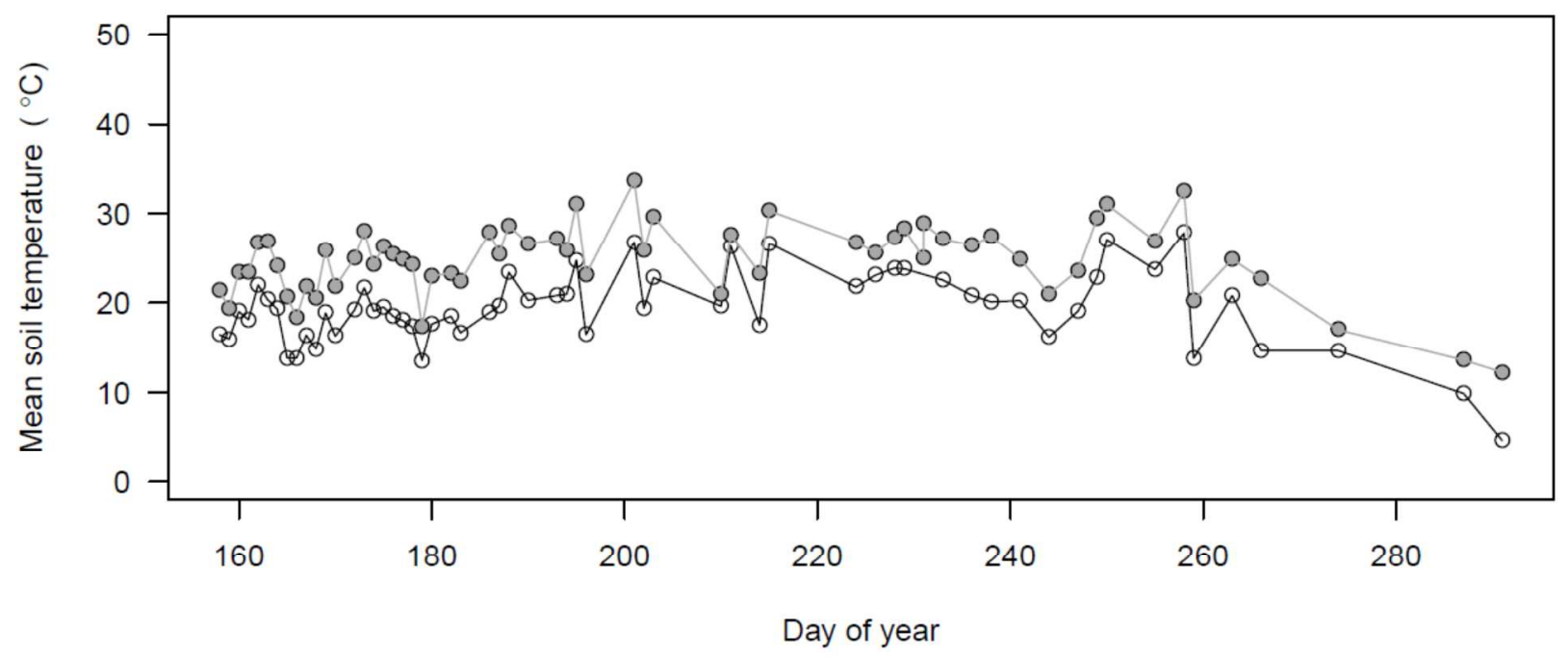

Supplemental Figure 1: Mean daily soil temperature $\left({ }^{\circ} \mathrm{C}\right.$ ) on soil warming treatments (grey) and ambient control treatments (white) during July - October 2015 at the Harvard Forest in Petersham, MA USA. Soil warming treatments averaged $5.3^{\circ} \mathrm{C}$ warmer than control treatments. 

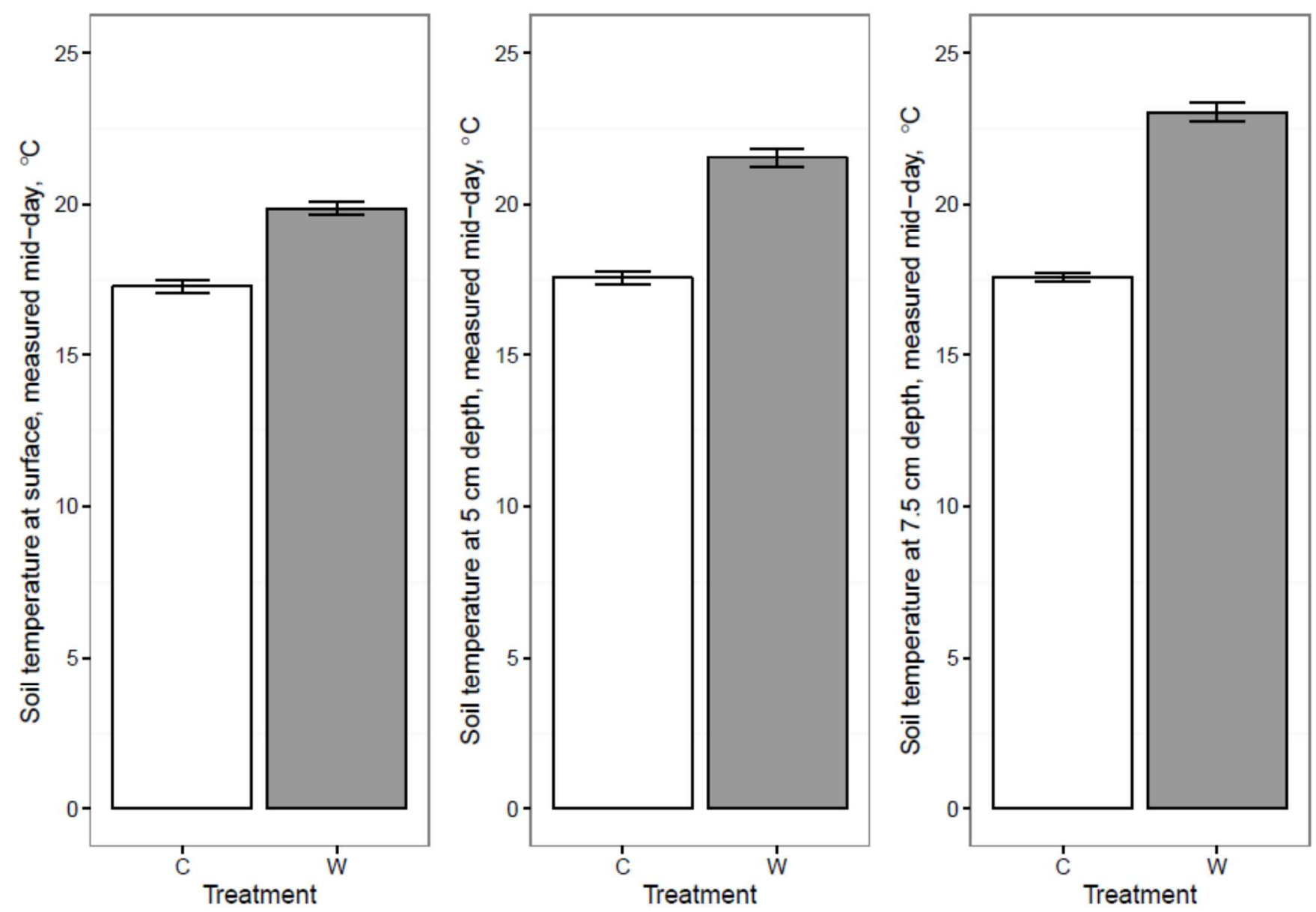

Supplemental Figure 2: Noon soil temperature $\left({ }^{\circ} \mathrm{C}\right)$ at soil surface $(2 \mathrm{~cm}$ depth $)$, at $5 \mathrm{~cm}$ depth and at $7.5 \mathrm{~cm}$ depth in soil warming treatments (W; grey) and ambient control treatments $(\mathrm{C}$; white) over three days in an $18^{\circ} \mathrm{C}$ greenhouse. Soil warming treatments were $2.6^{\circ} \mathrm{C}$ warmer at the soil surface, $4.0^{\circ} \mathrm{C}$ warmer at $5 \mathrm{~cm}$ below soil surface, and $5.5^{\circ} \mathrm{C}$ warmer at $7.5 \mathrm{~cm}$ below soil surface relative to control treatments. 

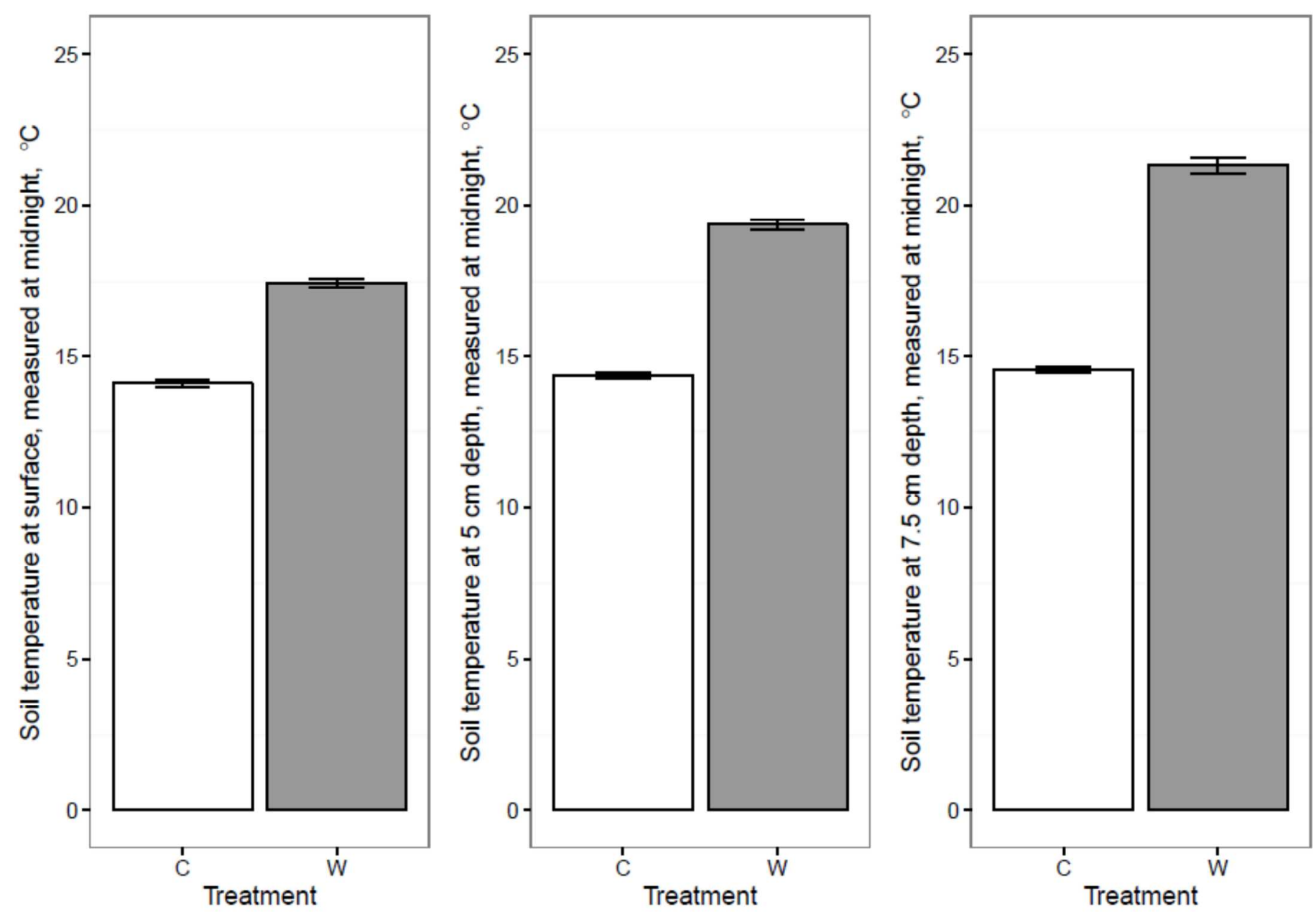

Supplemental Figure 3: Midnight soil temperature $\left({ }^{\circ} \mathrm{C}\right)$ at soil surface $(2 \mathrm{~cm}$ depth$)$, at $5 \mathrm{~cm}$ depth and at $7.5 \mathrm{~cm}$ depth on soil warming treatments (W; grey) and ambient control treatments $(\mathrm{C}$; white) over three days in a $15^{\circ} \mathrm{C}$ greenhouse. Soil warming treatments were $3.3^{\circ} \mathrm{C}$ warmer at the soil surface, $5.0^{\circ} \mathrm{C}$ warmer at $5 \mathrm{~cm}$ below soil surface, and $6.8^{\circ} \mathrm{C}$ warmer at $7.5 \mathrm{~cm}$ below soil surface relative to control treatments. 